\author{
Beata Ciupińska \\ Zespół Szkół Elektryczno-Elektronicznych, Radomsko
}

\title{
Doskonalenie relacji międzyludzkich wyzwaniem społeczeństwa XXI wieku
}

\section{WSPÓŁCZESNE UWARUNKOWANIA RELACJI MIĘDZYLUDZKICH}

Przedstawiciele nauk humanistycznych i społecznych mocno akcentują istnienie kryzysu więzi społecznej, do którego zdaniem Cz. Banacha (2002) dochodzi m.in. na skutek globalizacji życia społecznego, chaosu w zakresie reguł prawnych i obyczajowych, czy bezrobocia kształtującego poczucie niepewności. Osłabieniu więzi międzyludzkich sprzyja także coraz ostrzejszy kontrast dotyczący poziomu życia oraz możliwości ekonomicznych poszczególnych członków społeczeństwa. Od ludzi żyjących w tych specyficznych warunkach, czasach zawirowań i niepewności, oczekuje się jednak świadomego udziału w życiu społecznym i gospodarczym, podejmowania przemyślanych, dojrzałych decyzji oraz przyjmowania całkowitej odpowiedzialności ,za swój los”.

Nasuwa się pytanie jak sprostać temu wyzwaniu?

Warto skupić się na nawiązaniu pozytywnych, satysfakcjonujących relacji z innymi ludźmi, gdyż są oni niezbędni do osiągnięcia pełni szczęścia i poczucia spełnienia, a komunikacja międzyludzka jest jednocześnie warunkiem i skutkiem przebiegu socjalizacji. G. Filipiak (2000, s. 38) zwraca uwagę, że współcześnie najbardziej dowiedzioną kreatywną funkcją komunikacji jest tworzenie i integrowanie działań wspólnotowych, współpracy między osobami i integracji zbiorowości społecznych.

Pamiętając o tym, że umiejętności interpersonalne determinują kreowanie społeczności ludzi umiejących słuchać innych, rozumieć ich potrzeby i potrafiących konstruktywnie przezwyciężać konflikty - społeczności osób wierzących w swoją siłę i możliwości, warto przytoczyć wyodrębnione przez D. W. Johnsona (1992) cztery zakresy umiejętności decydujących o nawiązaniu i podtrzymywaniu zadowalających relacji z innymi:

- wzajemne poznanie i zaufanie,

- dokładne i jednoznaczne wzajemne zrozumienie,

- wzajemna pomoc,

- $\quad$ konstruktywne radzenie sobie z problemami i konfliktami.

\section{ISTOTA KOMUNIKACJI INTERPERSONALNEJ}

Komunikacja interpersonalna jest szczególnym przykładem wzajemnego oddziaływania na siebie ludzi $\mathrm{w}$ toku przekazywania i odbierania informacji. Punktem wyjścia do kształtowania umiejętności interpersonalnych jest poznanie własnej osobowości, uświadomienie sobie mocnych stron, po to, by rozwijać swój potencjał oraz słabych stron, aby 
wiedzieć co w sobie zmienić i ulepszyć. Odkrycie wewnętrznych przyczyn zachowań i zaakceptowanie siebie pozwala lepiej zrozumieć innych i zaaprobować ich.

\subsection{Umiejętności bazowe}

Filarami nawiązania pozytywnego kontaktu, w sytuacjach osobistych, towarzyskich czy zawodowych, są umiejętności podstawowe obejmujące sztukę słuchania, komunikowania informacji o sobie oraz wyrażania siebie (tego co myślimy, co widzimy, co czujemy i czego potrzebujemy). Okazywanie rozmówcy akceptacji, szacunku i serdeczności pomaga w kontaktach międzyludzkich, a ujawnianie informacji o sobie sygnalizuje stosunek do poruszanych kwestii oraz stopień zainteresowania rozmową.

Umiejętność dobrego słuchania wymaga zainteresowania się rozmówcą i skupienia na nim uwagi. Ważne jest również poza uważnym słuchaniem, przemyślenie i przekazanie informacji zwrotnej. Niezastąpione $\mathrm{w}$ tym względzie jest stosowanie technik aktywnego słuchania:

- parafrazowania - powtarzanie własnymi słowami sensu wypowiedzi partnera w celu upewnienia się, że właściwie zrozumieliśmy go;

- odzwierciedlanie - informowanie rozmówcy jakie według nas przeżywa uczucia w związku z przekazywanymi treściami;

- klaryfikacja - mobilizowanie partnera rozmowy, aby skoncentrował się na kwestiach najważniejszych.

Stosowanie powyższych technik sprawia, że kontakt staje się pełniejszy, a uczestnicy aktu komunikacji mają możliwość zrozumienia wzajemnych potrzeb oraz szansę na wspólne rozwiązanie problemów.

Techniki aktywnego słuchania służą także osiągnięciu konstruktywnego sprzężenia zwrotnego. Przekazywana w toku komunikacji informacja zwrotna pozwala spojrzeć na siebie i partnera rozmowy z innej perspektywy, stwarza możliwość uświadomienia sobie własnych zachowań i rozwijania kompetencji komunikacyjnych. Jest także okazją do sprostowania błędów interpretacyjnych i wyjaśnienia nieporozumień. Dobra informacja zwrotna powinna zatem być natychmiastowa (wypowiadana zaraz po zrozumieniu komunikatu), szczera (ma być prawdziwą reakcją adresata wypowiedzi) i wspierająca (przekazywana łagodnie i delikatnie, nie wywołująca reakcji obronnych rozmówcy) [McKay, Davis, Fanning, 2001].

Nawiązywaniu relacji z innymi sprzyja ponadto niezaprzeczalnie wiedza o stosowanych mechanizmach obronnych niszczących bliskość, specyfice sposobu komunikowania się uwarunkowanych płcią czy różnicami kulturowymi, przyjmowanych wewnętrznych rolach wypływających z analizy transakcyjnej oraz zasadach precyzowania wypowiedzi. Warto jednak pamiętać, że o skuteczności komunikacji mówimy tylko wówczas, gdy informacja nadawcy dokładnie oddaje jego intencję, a interpretacja odbiorcy zbiega się z zamiarami nadawcy (Johnson, 1992, s. 77). Ludzie porozumiewają się efektywnie tylko wówczas, gdy skupiają uwagę na tym samym.

\subsection{Komunikacja niewerbalna}

W procesie porozumiewania się ludzi ściśle wiążą się ze sobą dwa rodzaje komunikacji - werbalna i niewerbalna, to też niezbędne jest poznanie pozawerbalnych aspektów komunikacji międzyludzkiej: mowy ciała, parajęzyka (dźwiękowych ogniw wypowiedzi) i metakomunikatów (wiadomości o uczuciach i nastroju nadawcy).

Pozasłowne sygnały płynące $\mathrm{z}$ ciała przekazują szereg cennych informacji na temat wzajemnego stosunku do siebie rozmówców, wzmacniają komunikaty słowne, uzupełniają je, a czasem modyfikują. Warto pamiętać, że nawet nie wypowiadając słów ujawniamy swoje nastawienie i towarzyszące uczucia. Język ciała jest kopalnią wiedzy o słabo lub zupełnie nie uświadomionych uczuciach i reakcjach

Komunikaty niewerbalne pełnią szereg zadań w procesie komunikowania się ludzi:

- $\quad$ wyrażają uczucia i nastroje - poprzez mimikę, rodzaj spojrzeń, gestykulację, zabarwienie skóry itd. ; 
- ilustrują komunikaty werbalne - poprzez wizualną interpretację wypowiedzi np. kiwnięcie głową przy wyrażaniu zgody;

- regulują przebieg rozmowy i stosunki między rozmówcami - poprzez ruchy rąk, mimikę, westchnienia, np. sygnalizowanie podniesieniem ręki chęci zabrania głosu;

- służą przekazywaniu znaczeń - poprzez stosowanie emblematów, np. przesyłanie pocałunku to emblemat sympatii, puszczanie oka - wspólnoty;

- pozwalają dostosować się do aktualnej sytuacji - np. wygładzanie ubrania w celu uzyskania przychylności innych, poprawianie się na krześle przed zabraniem głosu w celu zajęcia najbardziej komfortowej pozycji.

Rozumienie komunikatów niewerbalnych jest istotną umiejętnością, gdyż ponad $50 \%$ znaczenia komunikatu zawiera się w ruchach ciała, a niemal $40 \%$ w sposobie wypowiadania treści (siła, głosu, rytm wypowiedzi, tempo itd.) [McKay, Davis, Fanning, 2001]. Chcąc nawiązać pozytywne relacje $\mathrm{z}$ innymi, warto docenić moc informacji zawartych w pozasłownych elementach przekazu, pamiętając jednak o tym, że komunikaty niewerbalne są wieloznaczne, a ich interpretacja jest uzależniona od osobistych doświadczeń i odczuć.

\subsection{Przezwyciężanie trudności w kontaktach interpersonalnych}

Wymienione wcześniej umiejętności wpływają na rozwój kolejnych kompetencji istotnych w relacjach interpersonalnych oraz przezwyciężaniu mogących ujawnić się $\mathrm{w}$ toku komunikacji międzyludzkiej barier i problemów. Postawa asertywna oraz sztuka konstruktywnego rozwiązywania konfliktów mają decydujące znaczenie w nawiązywaniu satysfakcjonyjących relacji z otoczeniem.

Przyczyną zaburzeń komunikacji międzyludzkiej, są blokady komunikacyjne powstające podczas określonych zachowań werbalnych. T. Gordon (1996) wymienia dwanaście opóźniających, przyhamowujących lub całkowicie zatrzymujących porozumienie blokad komunikacji interpersonalnej:

- nakazywanie, komenderowanie, polecanie;

- ostrzeganie, groźba;

- moralizowanie, głoszenie kazań;

- doradzanie, sugerowanie, proponowanie rozwiązań;

- pouczanie, robienie wykładu, dostarczanie logicznych argumentów;

- osądzanie, krytykowanie, dezaprobata;

- obrzucanie wyzwiskami, wyśmiewanie, ośmieszanie;

- interpretowanie, analizowanie, diagnozowanie;

- chwalenie, aprobowanie, wydawanie ocen pozytywnych;

- uspokajanie, okazywanie współczucia, pocieszanie;

- $\quad$ wypytywanie, indagowanie, krzyżowy ogień pytań;

- odwracanie uwagi, sarkazm, dowcipkowanie, zabawianie.

Warto zatem w relacjach międzyludzkich zadbać o stworzenie odpowiednich warunków do rozmowy, uwzględniać nastroje i oczekiwania partnera i unikając komunikatów zniechęcających do rozmowy, wzbudzających niechęć czy wrogość.

Umiejętność zaspokajania własnych potrzeb, wyrażania poglądów i określania wzajemnych stosunków bez niedomówień i naruszania praw innych - zachowanie asertywne, pozwala rozwiązać pomyślnie wiele trudnych sytuacji lub wręcz im zapobiec. Dzieje się tak dlatego, że poczucie godności drugiego człowieka, jego poczucie wartości pozostaje nienaruszone. M. McKay, M. Davis i P. Fanning (2001) podkreślają, że asertywność to nie cecha osobowości a umiejętność, którą można nabyć, jest zachowaniem społecznym, którego można się nauczyć.

Postrzeganie sytuacji spornych jako sprzeczności dzielących strony, przeszkód, które trzeba usunąć sprzyja rozwiązywaniu konfliktów, bo konflikty są składnikiem codzienności i tylko od sposobu ich rozwiązywania zależy czy niszczą czy wzmacniają relacje międzyludzkie. Przezwyciężenie konfliktu wymaga ustalenia jego źródła, prawidłowej diagnozy 
sprzeczności oraz wspólnych poszukiwań sposobów ich przezwyciężania. Radzenie sobie z konfliktem to znalezienie sposobów wyjścia z niego, ale przede wszystkim jest to umiejętność współpracy z partnerem w celu znalezienia możliwych do przyjęcia przez obydwie strony rozwiązań. Poznanie argumentów i stanowisk oraz dokładne przedstawienie punktów widzenia przez strony pomaga znaleźć konstruktywne rozwiązanie.

Jedną z możliwości są negocjacje dające wszystkim uczestnikom szansę zrealizowania swojego interesu pod warunkiem, że przebiegają w oparciu o następujące zasady:

- skoncentrowanie się na interesach a nie na stanowiskach;

- oddzielenie ludzi od problemu;

- poszukiwanie wielu wariantów rozwiązań problemu;

- opieranie rozstrzygnięć na kryteriach obiektywnych.

Osiągnięciu wzajemnego porozumienia w procesie komunikacji interpersonalnej, jak podkreśla G. Filipiak (2000), sprzyja zawsze: niedefensywne słuchanie (opanowanie emocji, aby nie przeszkadzały w słuchani), empatia (wczuwanie się w uczucia rozmówcy), odzwierciedlanie (upewnianie się, że dobrze zrozumieliśmy odczucia rozmówcy).

\section{ZNACZENIE UMIEJĘTNOŚCI INTERPERSONALNYCH W ŻYCIU CZLOWIEKA}

Komunikowanie się ludzi ze sobą jest procesem, który wyraża stan integracji życia zbiorowego ludzi. Niebagatelne staje się więc to, jak ludzie komunikują się ze sobą (Filipiak, 2000, s. 26). Współcześnie wzrasta ilość sytuacji, w których człowiek musi nawiązywać relacje z innymi. Praca coraz częściej wymaga radzenia sobie z ludźmi a nie rzeczami, zaspokajanie osobistych potrzeb czy realizacja celów także jest uwarunkowana współpracą z innymi, ważne jest więc, aby nawiązywane relacje dostarczały człowiekowi satysfakcji. Umiejętności interpersonalne decydują o pomyślności w relacjach międzyosobowych.

Z. Zaborowski (1997) zaznacza, że zmiany zachodzące we współczesnym świecie wymagają od ludzi przemieszczania się i zmiany miejsca pracy. Pociąga to za sobą konieczność nawiązywania nowych relacji. Umiejętne posługiwanie się technikami interpersonalnymi sprzyja nawiązywaniu nowych kontaktów i zacieśnianiu stosunków z ludźmi.

Człowiek podejmując działania prowadzące go do osiągnięcia celu natrafia na przeszkody, także relacje międzyosobowe często naznaczone są utrudnieniami. Mogą wówczas pojawić się konflikty prowadzące nawet do zachowań agresywnych uwarunkowanych reakcją emocjonalną na sytuację przeszkody. Sprawne posługiwanie się umiejętnościami interpersonalnymi pomaga $\mathrm{w}$ przezwyciężeniu kryzysu, chroni przed zerwaniem kontaktu z powodu niekontrolowanego wybuchu emocji.

Dlaczego jeszcze warto kształtować i doskonalić umiejętności interpersonalne? Ponieważ osoba posługująca się nimi:

- $\quad$ wyraża otwarcie własne opinie i odczucia;

- zachowuje się zgodnie z własnym sumieniem i postawą życiową;

- jest otwarta w relacjach z innymi;

- identyfikuje problemy i wykorzystuje różnorodne strategie i techniki ich rozwiązywania podejmując odpowiedzialne, przemyślane decyzje;

- łatwo nawiązuje kontakty i utrzymuje pozytywne, satysfakcjonujące relacje z innymi;

- potrafi współpracować w zespole zróżnicowanym charakterologicznie;

- radzi sobie w różnych sytuacjach życiowych;

- jest zadowolona z siebie.

Powyższe właściwości są także ważne dla rozumienia i ksztaltowania postaw przedsiębiorczych, które wymagają otwartości na informacje płynące z zewnątrz oraz umiejętności ich wykorzystania, a także podchodzenia do ujawniających się problemów bez emocji i uprzedzeń. 
R. Wawrzyniak-Beszterda (2002, s. 46-47) słusznie zauważa, że jeśli zatem człowiek ma być zdolny do aktywnego przekształcania zewnętrznej i wewnętrznej rzeczywistości, to musi dysponować umiejętnościami wchodzenia w różnego rodzaju interakcje, a podstawą tych umiejętności są m.in. kompetencje komunikacyjne.

\section{LITERATURA}

Banach Cz., 2002, Człowiek wobec wyzwań globalizacji i transformacji ustrojowej w Polsce, [w:] Pedagogika wobec zagrożeń, kryzysów i nadziei (red. T. Borowska). Kraków, „Impuls".

Gordon T., 1996, Wychowanie bez porażek w szkole. Warszawa, Instytut Wydawniczy PAX.

Filipiak G., 2000, Spoleczne aspekty barier w komunikacji interpersonalnej, [w:] Bariery w komunikowaniu (red. M. Golka). Poznań, Wyd. Naukowe.

Johnson D. W.,1992, Podaj dłoń. Warszawa, Instytut Psychologii Zdrowia i Trzeźwości.

McKay M., Davis M., Fanning P., 2001, Sztuka skutecznego porozumiewania się. Gdańsk, Gdańskie Wydawnictwo Psychologiczne.

Wawrzyniak-Beszterda R., 2002, Doświadczenia komunikacyjne uczniów w czasie lekcji. Studium empiryczne. Kraków, „Impuls”.

Zaborowski Z., 1997, Trening interpersonalny. Podstawy teoretyczne - procesy - techniki. Warszawa, Wydawnictwo Naukowe SCHOLAR. 